\title{
PREDICTORS OF THE NEED FOR INTENSIVE CARE UNIT ADMISSION IN ACUTE ORGANOPHOSPHORUS POISONING: ONE YEAR PROSPECTIVE STUDY
}

\author{
Situhom Elsayed Elagamy ${ }^{1}$, Hala Marawan Gabr ${ }^{2}$ \\ ${ }^{1}$ Lecturer of Forensic Medicine and Clinical Toxicology Department, ${ }^{2}$ Assistant professor of Public Health and Community Medicine \\ Department, Faculty of Medicine- Menoufia University
}

\begin{abstract}
Background: Organophosphorus (OP) poisoning is a very serious condition that needs rapid intervention and treatment. It can result from occupational, intentional or accidental exposure. Clinical manifestations include muscarinic, nicotinic and central effects which may be life threatening increasing the need for intensive care unit (ICU) management. Aim: The present study aims to identify the predictors which help in making timely decisions regarding transferring the patients for intensive care managements in acute organophosphorus poisoning. Material \& Methods: A prospective study included all 404 organophosphorus poisoning cases that were admitted to Menoufia Poison Control Center; Menoufia University Hospitals within the period from the beginning of January 2018 till the end of December 2018. Diagnosis of OP poisoning was based on history of exposure to OP compounds, characteristic clinical manifestations, low serum pseudo cholinesterase levels and detection of OP in the biological fluids by thin layer chromatography. Results: Organophosphorus poisoning was the $2^{\text {nd }}$ common cause of poisoning (15.02\% - 404 cases out of 2689) among cases admitted to Menoufia Poison Control Center during the period of the study. Majority of the cases managed at MPCC department while 83 patients (20.54\%) needed ICU admission. Most of the cases were suicidal and $94.31 \%$ were by oral exposures. $51.98 \%$ of the cases were poisoned by the liquid form of OP. Females outnumbered males. The majority of the cases were young students and single. There was statistically significant relation between pseudo cholinesterase activity and severity of the case according to POP classification (p value $<0.001$ ), the more the severity of poisoning the more suppression of pseudo cholinesterase level in the serum. Severe degree of POP classification, presence of hypoxia $(<50 \mathrm{mmHg}$ ), convulsions, and severe affection of serum cholinesterase activity were significantly predictors for patients who needed ICU admission. Conclusions: Severe degree of POP classification, presence of hypoxia, convulsions, and severe affection of serum cholinesterase activity are important predictors for ICU admission in OP poisoning.
\end{abstract}

Keywords: Organophosphorus, Pseudo cholinesterase, ICU, POP classification.

\section{INTRODUCTION}

Organophosphate (OP) compounds are widely used as agricultural pesticides. Organophosphorus poisoning can result from occupational, intentional or accidental exposure. Deliberate self-harm by suicidal poisoning is common all over the world (Tanveer et al., 2016).OP pesticide exposure occurs via inhalation, ingestion and dermal contact (Jokanović and Kosanović, 2010).

According to WHO,three million cases of pesticide poisoning occurs every year, out of which, about one million are accidental and two million are suicidal poisonings, resulting in more than 0.25 million deaths annually(Honnakatti et al., 2018).

Toxicity of OPs is the result of excessive cholinergic stimulation through inhibition of acetyl cholinesterase (AChE). The rapid accumulation of ACh in the synaptic junctions of central nervous system and peripheral tissues (disruption at cholinergic synapses) results in a cholinergic crisis, characterized by range of muscarinic, nicotinic, and central effects. The activity of AChE can drop to about $80 \%$ of normal before any symptoms occur and drop may upto $40 \%$ of normal before the symptoms become severe (Mumford and Troyer, 2011). The actions of ACh are removed by hydrolysis by AChE enzyme can only be reactivated very slowly.Paraoxonase1 (PON1) was first discovered through its ability to hydrolyse and therefore detoxify organophosphorus compounds (Mackness and Mackness, 2014).

\section{SUBJECTS AND METHODS}

A prospective study was carried out at Menoufia Poison Control Center; Menoufia University Hospitals, and included all 404 organophosphorus poisoning cases that were admitted from the beginning of January 2018 till the end of December 2018 after taking their informed valid
Clinical manifestations include; bradycardia, hypotension (Muscarinic), tachycardia (nicotinic), increased salivation/ lacrimation, excessive sweating, nausea \& vomiting, diarrhea, abdominalpain, \&fecal\& urinary incontinence. Hyperstimulation of the neuromuscular junction by acetylcholine initially results in fasciculation's, which is later followed by neuromuscular paralysis involving the ocular, bulbar, neck, proximal limb, and respiratory muscles in that order of severity. Muscle Paralysis may last for 2-18 days (Eddleston, 2002). CNS manifestation include Anxiety, restlessness, convulsion, insomnia, coma, chyene stokes breathing respiratory (Singh and Khurana, 2009).

The organophosphorus poisoning is a very serious condition that needs rapid treatment. Emergent and appropriate management is always desirable to prevent the serious complications and high mortality (Pyar et al., 2012)

Due to limited availability of facilities and resources in developing countries, all OP poisoning patients are not managed in intensive care units. Hence it is important to know factors that indicate the need for intensive care unit admission which should be identified in the initial examination.

consent. The study was approved by institutional ethical committee.

Diagnosis of OP poisoning was based on history of exposure to OP compounds, characteristic clinical manifestations, low serum pseudocholinesterase levels and detection of OP in the biological fluids by thin layer chromatography. 
Detailed history was taken from the patients or their relatives about the circumstances of poisoning, sociodemographic data (age, gender, residence, occupation, material status) interval between consumption of OP and arrival at the emergency department, type of OP compounds and route of exposure.

Clinical manifestations were assessed and clinical severity was categorized according to Peradeniya Organophosphorus Poisoning (POP) scale (Senanayake et al., 1993), which includes pupil size, respiratory rate, pulse rate, level of consciousness of the patient and presence or absence of convulsions and fasiculations. Based on this assessment a score was given to the patient, a score of 0 to 3 is considered as mild poisoning, 4-7 as moderate poisoning and 8-11 as a severe poisoning. The score was obtained at initial presentation before any medical intervention and it represented the muscarinic, nicotinic and central effects of the acute cholinergic manifestations of OP poisoning.

Pseudo cholinesterase levels (normal level 1900-3800 IU) were estimated by the method described by Waber (1966) for all patients and OP was detected in the biological fluids by thin layer chromatography (Kaplan et al., 1989).

Baseline investigations were done as indicated in the cases and all patients were dealt upto recovery or death from poisoning.

The data collected were tabulated and analyzed by SPSS (statistical package for social science) version 23.0 on IBM compatible computer.( SPSS Inc. Released 2015.IBM SPSS statistics for windows version 23,Armonk, NY: IBM Crop.)

Two types of statistics were done:

Descriptive statistics: e.g. percentage (\%), mean (x) and standard deviation (SD).

Analytic statistics:e.g.

- Chi-square test $\left(\chi^{2}\right)$ : was used to study association between two qualitative variables.

- Stepwise logistic regression: is a special case of the multiple linear regression which measures the relationship between the categorical dependent variable and one or more independent variables.

\section{RESULTS}

Organophosphorus poisoning was the $2^{\text {nd }}$ common cause of poisoning (15.02\% - 404 cases out of 2689) among cases admitted to Menoufia Poison Control Center during the period of the study after drug overdose $(22.78 \%)$ (Fig1). Majority of the cases managed at MPCC department while 83 patients $(20.54 \%)$ needed ICU admission. $42.08 \%$ of the cases aged 18-30 years old and there was significant difference between age and ICU admissions being higher among age group 18-30 years. Approximately two third of the cases were from rural background. Majority of the cases were suicidal and $94.31 \%$ were by oral exposures. All the inhalational and dermal exposures were accidental while all suicides were by ingestion. $51.98 \%$ of the cases were poisoned by the liquid form of OP. Malathion was the most commonly consumed OP $(41.84 \%)$ while parathion was predominantly consumed by the cases needed ICU admission and mechanical ventilation $(\mathrm{P}<0.001)$. Females outnumbered males. More than two third of the cases were singles $(68.07 \%)$. Students were the commonest to be poisoned by OP $(27.97 \%)$, also there was significant relationship between occupation and ICU admissions being higher among students. Regarding referral data, non-referred cases $(53.22 \%)$ outnumbered referred ones. Most of the patients $(82.92 \%)$ came to MPCC within the $1^{\text {st }} 6$ hours of exposure, while most of the cases entered ICU presented to the center within more than 6 hours after exposure $(\mathrm{P}<0.001)$. The period of hospitalization was less than one week in most of the cases and the majority of ICU admissions stayed more than a week especially severe cases that needed mechanical ventilation $(\mathrm{P}<0.001)($ table 1$)$. The main manifestations at time of admission were vomiting/abdominal pain (88.61\%),miosis $(85.89 \%)$,sweating/lacrimation/salivations

(68.07\%),bronchorrhea/tachypnea $\quad(58.17 \%)$, bradycardia (56.19\%),fasciculations/muscle weakness, disturbed consciousness, incontinence and convulsions. Vomiting was predominant in the cases that managed at department, while fasciculations/muscle weakness, disturbed consciousness, bronchorrhea/tachypnea, bradycardia, incontinence, convulsions and very low pseudo cholinesterase levels ( $<10 \%$ activity) were mostly seen in the cases that managed at ICU $(\mathrm{p}<0.001)$. Most of the cases that developed acidosis (metabolic/respiratory) needed ICU admission and all cases with severe hypoxia (PO2 < 50 $\mathrm{mmHg}$ ) also admitted to ICU and needed ventilator support. 11 patients of the ICU admitted cases suffered from increased creatinine level especially those with prolonged period of stay (table 2). The mean values of pseudocholinesterase enzyme were $1129.8 \pm 160.1 \mathrm{U} / \mathrm{L}$, 617.3 $\pm 113.9 \mathrm{U} / \mathrm{L}$ and $259.7 \pm 55.6 \mathrm{U} / \mathrm{L}$ for mild, moderate and sever cases respectively (Fig 2). As per POP scale, $55.20 \%, 24.26 \%$ and $20.54 \%$ of the cases were mild, moderate and severe and all the severe cases needed ICU admissions. Almost all cases survived and only $1.73 \%$ died ( 7 cases), the deaths were in the severe group that needed ICU admission and were commonly due to acute respiratory distress syndrome and respiratory failure (table 3).There was statistically significant relation between pseudo cholinesterase activity and severity of the case according to POP classification ( $\mathrm{P}$ value $<0.001$ ), the more the severity of poisoning the more suppression of pseudo cholinesterase level in the serum (table4). Severe degree of POP classification, presence of hypoxia $(<50 \mathrm{mmHg})$, convulsions and severe affection of serum cholinesterase activity $(<10 \%)$ were significantly predictors for patients who needed ICU admission (table5). 


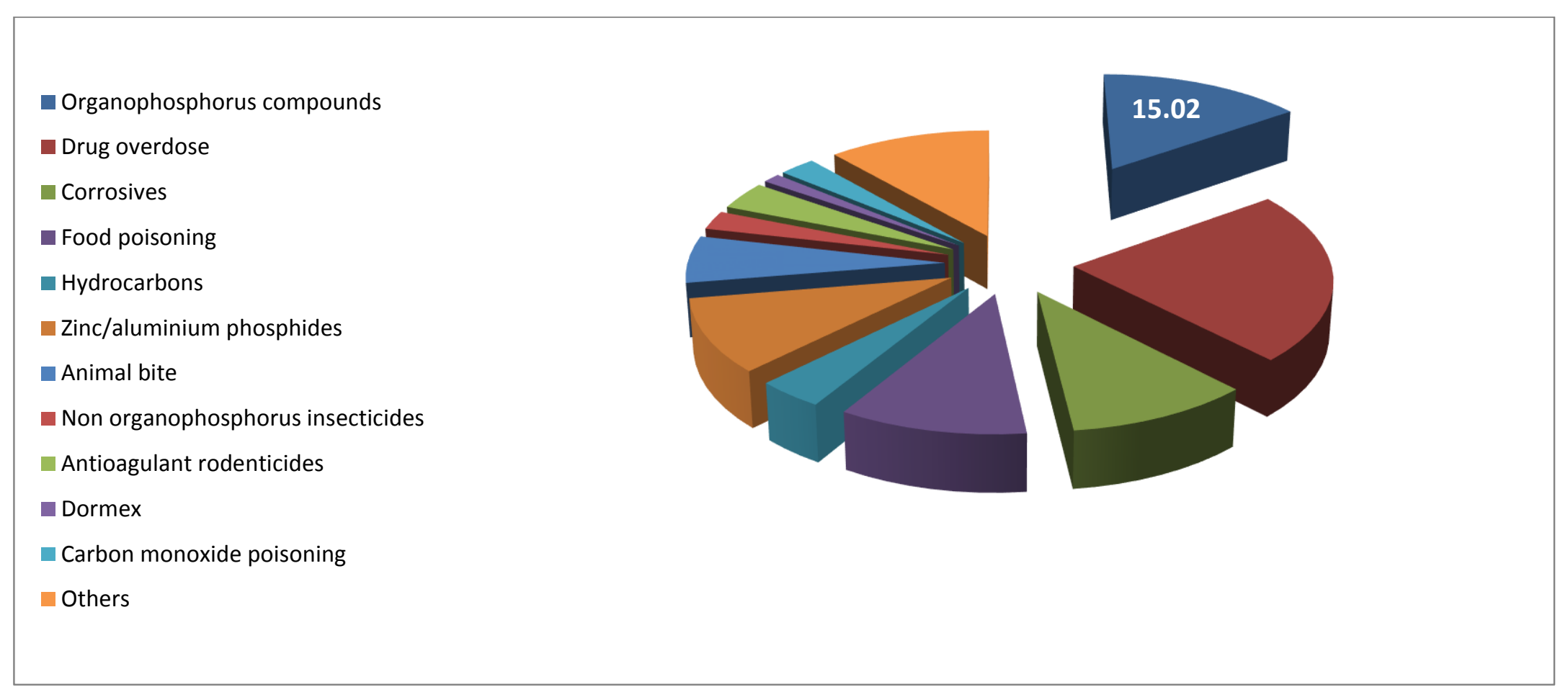

Fig (1): Causes of Poisoning Among Cases Admitted to Menoufia Poison Control Center during the Period of the Study

Table (1): Risk factors of Acute Organophosphorus Poisoning and ICU admission.

\begin{tabular}{|c|c|c|c|c|c|}
\hline & $\begin{array}{l}\text { Department } \\
\text { (321) }\end{array}$ & $\begin{array}{l}\text { ICU } \\
(83)\end{array}$ & $\begin{array}{l}\text { Total } \\
(\mathbf{4 0 4 )} \\
\end{array}$ & Test of significance & P value \\
\hline $\begin{array}{l}\text { Age } \\
<18 \\
18-30 \\
30-50 \\
>50\end{array}$ & $\begin{array}{l}52(16.20 \%) \\
121(37.69 \%) \\
126(39.26 \%) \\
22(6.85 \%)\end{array}$ & $\begin{array}{l}15(18.07 \%) \\
49(59.04 \%) \\
11(13.25 \%) \\
8(9.64 \%)\end{array}$ & $\begin{array}{l}67(16.58 \%) \\
170(42.08 \%) \\
137(33.91 \%) \\
30(7.43 \%)\end{array}$ & 23.25 & $<0.001$ \\
\hline $\begin{array}{l}\text { Sex } \\
\text { Male } \\
\text { Female }\end{array}$ & $\begin{array}{l}153(47.66 \%) \\
168(32.34 \%)\end{array}$ & $\begin{array}{l}36(43.37 \%) \\
47(56.63 \%)\end{array}$ & $\begin{array}{l}189(46.78 \%) \\
215(53.22 \%)\end{array}$ & 0.49 & 0.485 \\
\hline $\begin{array}{l}\text { Residence } \\
\text { Urban } \\
\text { Rural }\end{array}$ & $\begin{array}{l}117(36.45 \%) \\
204(63.55 \%)\end{array}$ & $\begin{array}{l}24(28.92 \%) \\
59(71.08 \%)\end{array}$ & $\begin{array}{l}141(34.91 \%) \\
263(65.09 \%)\end{array}$ & 1.65 & 0.199 \\
\hline $\begin{array}{l}\text { Occupation } \\
\text { Student } \\
\text { House wife } \\
\text { Farmer } \\
\text { Worker } \\
\text { Employee } \\
\text { Not working }\end{array}$ & $\begin{array}{l}61(19.00 \%) \\
67(20.87 \%) \\
57(17.76 \%) \\
51(15.89 \%) \\
25(7.79 \%) \\
60(18.69 \%)\end{array}$ & $\begin{array}{l}52(62.65 \%) \\
11(13.25 \%) \\
2(2.41 \%) \\
2(2.41) \\
0(0.00 \%) \\
16(19.28 \%)\end{array}$ & $\begin{array}{l}113(27.97 \%) \\
78(19.31 \%) \\
59(14.60 \%) \\
53(13.12 \%) \\
25(6.19 \%) \\
76(18.81 \%)\end{array}$ & 73.15 & $<0.001$ \\
\hline $\begin{array}{l}\text { Marital status } \\
\text { Married } \\
\text { Single }\end{array}$ & $\begin{array}{l}98(30.53 \%) \\
223(69.47 \%)\end{array}$ & $\begin{array}{l}31(37.35 \%) \\
52(62.65 \%)\end{array}$ & $\begin{array}{l}129(31.93 \%) \\
275(68.07 \%)\end{array}$ & 1.41 & 0.234 \\
\hline $\begin{array}{l}\text { Route of exposure } \\
\text { Oral } \\
\text { Inhalation/dermal }\end{array}$ & $\begin{array}{l}299(93.15 \%) \\
22(6.85 \%)\end{array}$ & $\begin{array}{lc}82 & (98.80 \%) \\
1 & (1.20 \%)\end{array}$ & $\begin{array}{l}381(94.31 \%) \\
23(5.69 \%)\end{array}$ & 4.17 & 0.041 \\
\hline $\begin{array}{l}\text { Mode of exposure } \\
\text { Accidental } \\
\text { Suicidal } \\
\end{array}$ & $\begin{array}{l}55(17.13 \%) \\
266(82.87 \%)\end{array}$ & $\begin{array}{l}9(10.84 \%) \\
74(89.16 \%)\end{array}$ & $\begin{array}{l}64(15.84 \%) \\
340(84.16 \%)\end{array}$ & 1.96 & 0.161 \\
\hline $\begin{array}{l}\text { Form } \\
\text { Powder } \\
\text { Fluid } \\
\end{array}$ & $\begin{array}{l}159(49.53 \%) \\
162(50.47 \%)\end{array}$ & $\begin{array}{l}35(42.17 \%) \\
48(57.83 \%)\end{array}$ & $\begin{array}{l}194(48.02 \%) \\
210(51.98 \%)\end{array}$ & 1.43 & 0.231 \\
\hline $\begin{array}{l}\text { Type } \\
\text { Unknown } \\
\text { Malathion } \\
\text { Parathion }\end{array}$ & $\begin{array}{l}134(41.74 \%) \\
152(47.35 \%) \\
35(10.91 \%)\end{array}$ & $\begin{array}{l}23(27.71 \%) \\
17(20.48 \%) \\
43(51.81 \%)\end{array}$ & $\begin{array}{l}157(38.86 \%) \\
169(41.83 \%) \\
78(19.31 \%)\end{array}$ & 71.87 & $<0.001$ \\
\hline $\begin{array}{l}\text { Referral } \\
\text { Yes } \\
\text { No }\end{array}$ & $\begin{array}{l}151(47.04 \%) \\
170(52.96 \%)\end{array}$ & $\begin{array}{l}38(45.78 \%) \\
45(54.22 \%)\end{array}$ & $\begin{array}{l}189(46.78 \%) \\
215(53.22 \%)\end{array}$ & 0.49 & 0.485 \\
\hline $\begin{array}{l}\text { Time interval } \\
<=6 \text { hours } \\
>6 \mathrm{hrs}\end{array}$ & $\begin{array}{l}305(95.02 \%) \\
16 \quad(4.98 \%)\end{array}$ & $\begin{array}{l}30(36.14 \%) \\
53(63.86 \%)\end{array}$ & $\begin{array}{l}335(82.92 \%) \\
69(17.08 \%)\end{array}$ & 161.39 & $<0.001$ \\
\hline $\begin{array}{l}\text { Period of stay } \\
<=7 \text { days } \\
>7 \text { days }\end{array}$ & $\begin{array}{l}318(99.07 \%) \\
3(0.93 \%)\end{array}$ & $\begin{array}{l}15(18.07 \%) \\
68(81.93 \%)\end{array}$ & $\begin{array}{l}333(82.43 \%) \\
71 \quad(17.57 \%)\end{array}$ & 298.65 & $<0.001$ \\
\hline
\end{tabular}


Table (2): Chi Square Analysis of Clinical Manifestations and Investigations between Department and ICU Cases of Acute Organophosphorus Poisoning.

\begin{tabular}{|c|c|c|c|c|c|}
\hline & $\begin{array}{l}\text { Department } \\
\text { (321) }\end{array}$ & $\begin{array}{l}\text { ICU } \\
(83) \\
\end{array}$ & $\begin{array}{l}\text { Total } \\
(404)\end{array}$ & Test of significance & $\overline{P \text { value }}$ \\
\hline Vomiting / Abdominal pain & $293(91.27 \%)$ & $65(78.31 \%)$ & $358(88.61 \%)$ & 10.99 & $<0.001$ \\
\hline Stool and urine incontinence & $53(16.51 \%)$ & $60(72.29 \%)$ & $113(27.97 \%)$ & 101.84 & $<0.001$ \\
\hline Miosis & $270(95.40 \%)$ & $77(92.77 \%)$ & $347(85.89 \%)$ & 4.08 & 0.043 \\
\hline Sweating and salivation & $242(75.40 \%)$ & $43(51.81 \%)$ & $275(68.07 \%)$ & 0.02 & 0.896 \\
\hline Bronchorrhea/tachypnea & $165(51.40 \%)$ & $70(84.34 \%)$ & $235(58.17 \%)$ & 29.40 & $<0.001$ \\
\hline Bradycardia / hypotension & $150(46.73 \%)$ & $77(92.77 \%)$ & $227(56.19 \%)$ & 56.79 & $<0.001$ \\
\hline Fasciculation /hypotonia & $85(26.48 \%)$ & $73(87.95 \%)$ & $158(39.11 \%)$ & 104.65 & $<0.001$ \\
\hline Convulsions & $0(0.00 \%)$ & $13(15.66 \%)$ & $13(3.22 \%)$ & 51.95 & $<0.001$ \\
\hline Disturbed consciousness & $0(0.00 \%)$ & $80(96.39 \%)$ & $134(33.17$ & 188.33 & $<0.001$ \\
\hline Acidosis & $11(3.42 \%)$ & $73(87.95 \%)$ & $84(20.79 \%)$ & 286.09 & $<0.001$ \\
\hline Hypoxia (PO2 < 50 mmHg) & $0(0.00 \%)$ & $72(86.75 \%)$ & $72(17.82 \%)$ & 338.85 & $<0.001$ \\
\hline Increased creatinine & $0(0.00 \%)$ & $11(13.25 \%)$ & $11(2.72 \%)$ & 43.73 & $<0.001$ \\
\hline $\begin{array}{l}\text { Pseudo cholinesterase level } \\
20-50 \%(1129.8 \pm 160.1) \\
10-20 \%(617.3 \pm 113.9) \\
<10 \%(259.7 \pm 55.6)\end{array}$ & $\begin{array}{l}218(67.91 \%) \\
99(30.84 \%) \\
4(1.25 \%)\end{array}$ & $\begin{array}{l}0(0.00 \%) \\
2(2.41 \%) \\
81(97.59 \%)\end{array}$ & $\begin{array}{l}218(53.96 \%) \\
101(25.00 \%) \\
85(21.04 \%) \\
\end{array}$ & 368.64 & $<0.001$ \\
\hline
\end{tabular}

Table (3): Chi Square Analysis of Severity and Outcome between Department and ICU Cases of Acute Organophosphorus Poisoning.

\begin{tabular}{|c|c|c|c|c|c|}
\hline & $\begin{array}{l}\text { Department } \\
\text { (321) }\end{array}$ & $\begin{array}{l}\text { ICU } \\
(83)\end{array}$ & $\begin{array}{l}\text { Total } \\
(404)\end{array}$ & Test of significance & P value \\
\hline $\begin{array}{l}\text { POP classification } \\
\text { Mild } \\
\text { Moderate } \\
\text { Severe }\end{array}$ & $\begin{array}{l}223(69.47 \%) \\
98(30.53 \%) \\
0(0.00 \%)\end{array}$ & $\begin{array}{l}0(0.00 \%) \\
0(0.00 \%) \\
83(100.0 \%)\end{array}$ & $\begin{array}{l}223(55.20 \%) \\
98(24.26 \%) \\
83(20.54 \%)\end{array}$ & 404.00 & $<0.001$ \\
\hline $\begin{array}{l}\text { Outcome } \\
\text { Cured } \\
\text { Died }\end{array}$ & $\begin{array}{l}321(100.0 \%) \\
0 \quad(0.00 \%)\end{array}$ & $\begin{array}{l}76(91.57 \%) \\
7 \quad(9.43 \%)\end{array}$ & $\begin{array}{l}397(98.27 \%) \\
7(1.73 \%)\end{array}$ & 27.55 & $<0.001$ \\
\hline
\end{tabular}

Table (4): Relation between Pseudo Cholinesterase Level and Degree of Severity by POP Classification.

\begin{tabular}{|c|c|c|c|c|c|}
\hline \multirow[t]{2}{*}{ POP classification } & \multicolumn{3}{|c|}{ Pseudo cholinesterase level } & \multirow{2}{*}{ Total } & \multirow[t]{2}{*}{$\overline{\text { Chi square ( } p \text { value ) }}$} \\
\hline & $<10 \%$ & $10-20 \%$ & $20-50 \%$ & & \\
\hline Mild & $0(0.0 \%)$ & $5(4.95 \%)$ & $218(100 \%)$ & $223(55.1 \%)$ & \multirow{4}{*}{$\begin{array}{c}756.93 \\
(<0.001)\end{array}$} \\
\hline Moderate & $2(2.35 \%)$ & $96(95.05 \%)$ & $0(0.0 \%)$ & $98(24.25 \%)$ & \\
\hline Severe & $83(97.65 \%)$ & $0(0.0 \%)$ & $0(0.0 \%)$ & $83(20.54)$ & \\
\hline Total & $85(100 \%)$ & $101(100 \%)$ & $218(100 \%)$ & 404 & \\
\hline
\end{tabular}

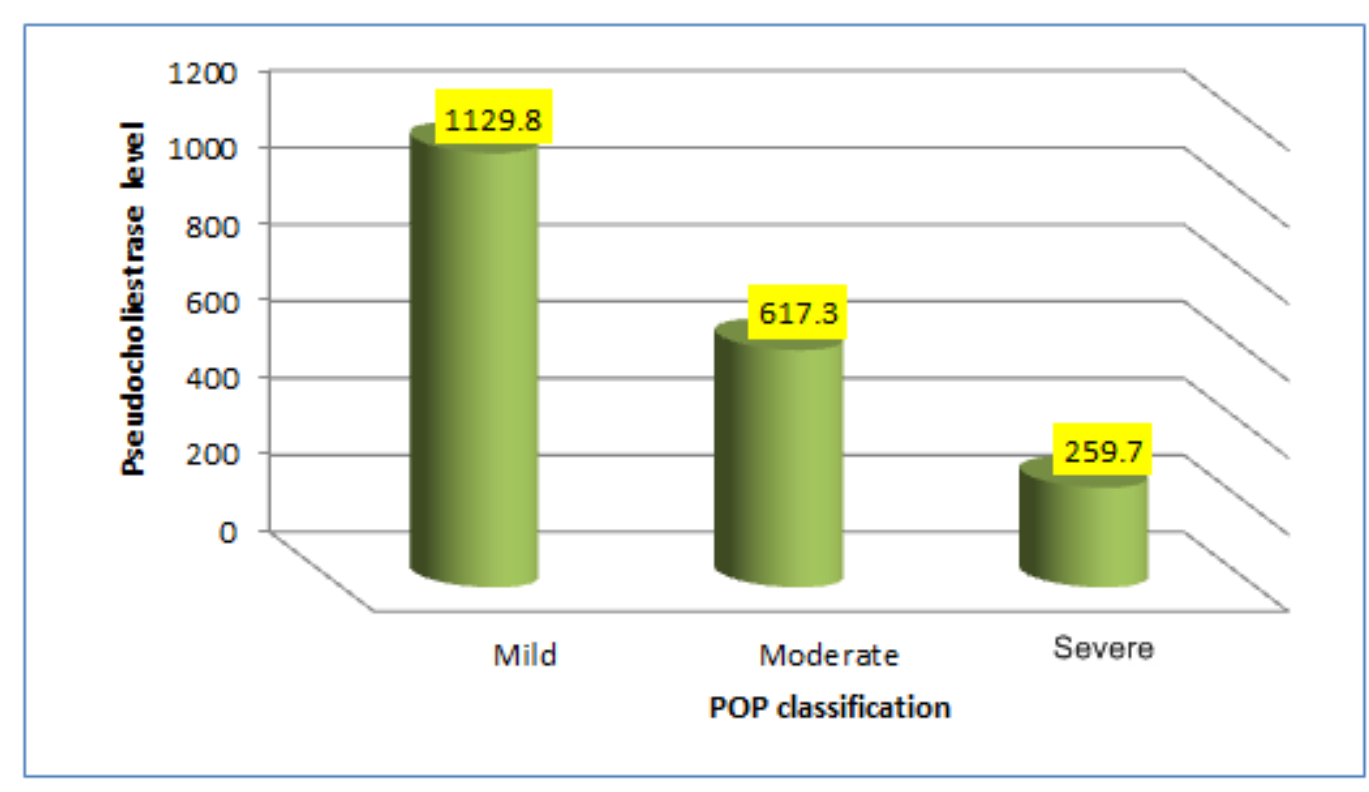

Fig (2): Relation between Pseudo Cholinesterase Level and Degree of Severity by POP Classification. 
Table (5): Regression (step-wise logistic) Predictors for ICU admission.

\begin{tabular}{|l|c|c|c|}
\hline \multicolumn{1}{|c|}{ Risk factors } & Odds ratio & P-value & 95\% CI \\
\hline Pop classification (severe versus mild) & 1.87 & 0.046 & $1.12-3.19$ \\
\hline $\begin{array}{l}\text { Cholinesterase level <10\% (reference is } \\
\mathbf{2 0 - 5 0 \% )}\end{array}$ & 2.84 & 0.017 & $1.40-5.67$ \\
\hline Hypoxia (PO2 < 50 $\mathbf{m m H g})$ & 2.59 & 0.016 & $1.86-3.28$ \\
\hline Convulsions & 2.51 & 0.02 & $1.16-5.43$ \\
\hline
\end{tabular}

\section{DISCUSSION}

Organophosphate poisoning is one of the health problems presents worldwide and is responsible for many morbidities and mortalities especially in developing countries (Eddleston, 2002; Guven et al., 2002). Huge human and financial resources are consumed by intensive care services and so the identification of predictors for ICU admission may help to limit the use of these resources (Angus et al., 2006; Ibrahim et al., 2011).

The present study showed that organophosphate poisoning (OP) was the second most common cause of poisoning among the cases admitted to Menoufia Poison Control Center during the period of study after drug overdose. Menoufia is an agriculture-based governorate and OP compounds are widely used for protection of crops and pest control. Their easy availability and low cost make them preferable for self-deliberate poisoning. According to Eddleston et al., (2008) organophosphates are commonly used insecticides in many settings globally either agricultural or domestic which may lead to large number of admissions to hospital due to poisoning. Also majority of pesticide poisoning were due to organophosphate compounds and this is supported by Blumenberg et al., (2018).

Majority of the cases managed at MPCC department while 83 patients $(20.54 \%)$ needed ICU admission. $42.08 \%$ of the cases aged 18-30 years old and there was significant difference between age and ICU admissions being higher among age group 18-30 years. The people in this age group are more prone to various emotional stress and conflicts (family problems, learning problems, academic failures, depression and psychosis) as they are usually known to be more ambitious, active and productive persons. This is in agreement with Ravikumar and Piyush (2016) who found that $46 \%$ of their cases were located in the age group of 1830 year, also Chataut et al., (2011) indicated that $40 \%$ of the cases aged 25-35 years old.

Majority of the cases were suicidal and $94.31 \%$ were by oral exposures. All the inhalational and dermal exposures were accidental while all suicides were by ingestion. A study made in India by Chaudhary et al., (2013) supported these findings. Also oral exposure and suicidal attempt were significantly higher among ICU patients as $\mathrm{p}<0.05$. Persons who tend to harm themselves usually ingest large amounts of rapidly acting highly toxic compounds and so more poisoning severity with increasing need to ICU support.

Female outnumbered males. As indicated before most of the cases were suicidal and female are more sensitive and can be affected easily by the various life conflicts which may make them react with aggressive behaviors against themselves or others. This finding is consistent with many studies done in different parts of the world (Karki et al., 2004: Pokhrel et al., 2008; Jasem et al., 2014) while Ali et al., (2012) found that males were the commonest among their cases.

Approximately two third of the cases were from rural background. Menoufia is an agriculture-based rural governorate with extensive use of organophosphate compounds in agriculture and their common presence and easy availability in rural dwellers homes. Eddleston and Phillips (2004) and Prasad et al., (2013) reported similar finding.

Students were the commonest to be poisoned by OP $(27.97 \%)$, also there was significant relationship between occupation and ICU admissions being higher among students. Their impulsive immature thinking and their exposure to many stresses (learning problems, failure in exams, unsuccessful love affairs...etc) make them victims to suicidal ideations. Hassan and Madboly (2013) concluded the same result. Chataut et al., (2011) and Prasad et al., (2013) found that agricultural workers topped their list while it was unemployed in the study done by Ibrahim et al., (2011). More than two third of the cases were singles $(68.07 \%)$ as the majority of the cases were young, also marriage with responsibility about family and children make the person less affected by suicidal thoughts. Regarding referral data, non-referred cases (53.22\%) outnumbered referred ones as patient relatives may prefer to take him directly to MPCC as it is the only specialized toxicology center in Menoufia and the surrounding localities.

Malathion was the most commonly consumed OP (41.84\%) which is consistent with a study done in Bangladesh by Dewan (2014), while Raghavan et al., (2014) reported that methyl parathion and chlorpyrifos were the commonest substances ingested by their cases. Parathion was predominantly consumed by the cases needed ICU admission and mechanical ventilation ( $\mathrm{p}<0.001)$, Madala et al., (2017) indicated similar finding. World Health Organization (WHO) classified parathion as toxicity class Ia (extremely hazardous) (Rao and Kumar, 2012), leading to severe toxicity which needs rapid and proper management.51.98\% of the cases were poisoned by the liquid form of OP, which is inconsistent with another investigation done by Adinew et al., (2017). There may be difference in the availability of different physical and chemical forms of the compounds between different parts of the world even between the different parts of the same country.

Most of the patients (82.92\%) came to MPCC within the $1^{\text {st }} 6$ hours of exposure while most of the cases entered ICU presented to the center within more than 6 hours after 
exposure $(\mathrm{p}<0.01)$. The lag time between the exposure and start of treatment plays an important role in the efficacy of treatment and so patients' prognosis. Also the delay in treatment will lead to development of more severe complications which commonly require ICU admission. Chaudhary et al., (2013) and Taromsari et al., (2013) supported these findings as they found that the majority of their cases presented to hospital within $6 \mathrm{~h}$ of exposure. Shah et al., (2015) reported that most of their cases reached the hospital $4 \mathrm{~h}$ after the exposure and stressed on the importance of early admission and treatment. According to Ahmed et al., (2014) there is a linear and positive correlation between lag time and the need for mechanical ventilation and ICU admission.

The period of hospitalization was less than one week in most of the cases as the manifestations were between mild and moderate in almost all of them. The majority of ICU admissions stayed more than a week especially severe cases that needed mechanical ventilation $(p<0.001)$. Similar observations were made by other studies in which the duration of stay in hospital was higher in severe cases that needed ICU and mechanical ventilation (Chaudhary et al., 2013; Raddi and Anikethana, 2014).

As per POP scale, $55.20 \%, 24.26 \%$ and $20.54 \%$ of the cases were mild, moderate and severe and all the severe cases needed ICU admissions. These findings are compatible with the results of previous investigations (Taromsari et al., 2013; Shah et al., 2015). By using Dreisbach's classification Ahmed et al., (2014) found that $48.8 \%$ of patients were severely poisoned, while Ali et al., (2012) reported that most of their cases were moderate (60\%) by application of W.H.O. classification for OP poisoning severity. These variations in results may be due to different study design and use of different severity scales.

Almost all cases survived and only $1.73 \%$ died Eddleston et al., (2008) found marked variations in the mortality rate reported by hospitals in different parts of the world ranging from $1.85 \%$ in Mach Maihospital Poison Control Centre, Vietnam (Zilker and Hibler, 1996) to $40 \%$ in a German ICU (Eyer et al., 2002). Eddleston et al., (2005) attributed variation in OP fatality rates to difference in chemistry and forms of OP compounds in different parts of the world which may alter treatment efficacy and cases outcome.

The deaths were in the severe group that needed ICU admission and were commonly due to acute respiratory distress syndrome and respiratory failure. The findings are comparable with other studies (Prasad et al., 2013).

The clinical findings were variable and the muscarinic manifestations were more presented than nicotinic and CNS manifestations and this was also observed by Ravikumar and Piyush (2016). Organophosphates inactivate the acetyl cholinesterase enzyme with accumulation of acetylcholine within the nervous system which cause excessive stimulation of the muscarinic and nicotinic receptors leading to muscarinic manifestations( increased body secretions, GIT distress, stool and urine incontinence, bronchospasm and bradycardia), nicotinic manifestations ( muscle weakness, fasciculations and paralysis) and CNS manifestations (restlessness, anxiety, convulsions and coma)(Singh et al., 2016; Blumenberg et al., 2018). The main manifestations at time of admission were vomiting/abdominal pain $(88.61 \%)$, miosis $(85.89 \%)$, sweating/lacrimation/salivations

$(68.07 \%)$ bronchorrhea/tachypnea (58.17\%), bradycardia (56.19\%),fasciculations/muscle weakness, disturbed consciousness, incontinence and convulsions. A study in Karnataka, India done by Badiger and Harish (2017) showed that vomiting and sweating followed by miosis were the commonly noted clinical findings while Banday et al., (2016) indicated that miosis ,salivation ,incontinence, anxiety and restlessness were the most consistent manifestations. Vomiting was predominant in the cases that managed at department as the patients get rid of large amount of the poison in vomitus leading to less effect and severity, while fasciculations/muscle weakness, disturbed consciousness, bronchorrhea/tachypnea, bradycardia, incontinence, convulsions and very low pseudo cholinesterase levels ( $<10 \%$ activity) were mostly seen in the cases that managed at ICU $(\mathrm{p}<0.001)$. Rajeev and Arvind (2013) similarly supported these findings as they increased the need for and duration of ventilator support and ICU admissions. Patil and Vasepalli (2014) reported that most cases of disturbed consciousness needed ICU admission and pseudo cholinesterase levels correlated well with poisoning severity and the need for ventilator support.

Most of the cases that developed acidosis (metabolic/respiratory) needed ICU admission. Acidosis occurs commonly in acute OP poisoning which may be as a complication to hypotension or hypoventilation and this supported by Erdman (2004).

All cases with severe hypoxia $(\mathrm{PO} 2<50 \mathrm{mmHg})$ also admitted to ICU and needed ventilator support and 11 patients of the ICU admitted cases suffered from increased creatinine level especially those with prolonged period of stay. Rajeev and Arvind (2013) similarly found that mechanical ventilation were needed for the patient with $\mathrm{PO} 2<60 \mathrm{mmHg}, \mathrm{PH}<7.2$, apnea, persistent cyanosis and tachypnea. Liu et al., (2008) also indicated that acid base disturbance correlate well with poisoning severity, need for ICU admission and patients outcome.

There was a significant -ve correlation between serum cholinesterase activity and severity of the cases according to POP scale, indicating its importance as a useful marker in assessment of OP poisoning severity. Khan et al., (2016) concluded the same results, also Tripathi (2014) indicated a significant relation between need for ventilation support and affection of serum cholinesterase activity.

\section{RECOMMENDATIONS}

1-Health education should be done to the public about the dangers of organophosphorus compounds and restriction of their availability especially to young age.

2-Management protocols should be available at toxicology centers especially for alarming signals for ICU admissions.

\section{REFERENCE}

Adinew, G.M.; Asrie, A.B. and Birru, E.M. (2017): Pattern of acute organophosphorus poisoning at University of Gondar Teaching Hospital, Northwest Ethiopia. BMC Res Notes, 10:149.

Ahmed, S.M.; Das, B.; Nadeem, A. and Samal, R.K.(2014): Survival pattern in patients with acute organophosphate poisoning on mechanical ventilation: A retrospective intensive care unit-based study in a tertiary care teaching hospital. Indian J Anaesth,58(1): $11-17$. 
Ali, P.; Anwer, A.; Bashir, B.; Jabeen, R.; Haroon, H. and Makki, K. (2012): Clinical pattern and outcome of organophosphorus poisoning. J Liaq Uni Med Health Sci, 11(1):15-8.

Angus, D.C.; Shorr, A.F. and White, A. (2006): Critical care delivery in the United States: distribution of services and compliance with Leapfrog recommendations. Crit Care Med, 34:1016-1024.

Badiger, S. and Harish, J. (2017): Study the Clinical and Electrocardiographic Changes in Organophosphorus Poisoning. Sch. J. App. Med. Sci., 5(9D):3738-3743.

Banday, T.H.; Bashir, S.; Naik,V. and Baharat(2016): Predictors of Morbidity \& Mortality in Organophosphorus Poisoning: A Case Study in Rural Hospital of Karnataka.J Medicine , 17: 3-7.

Blumenberg, A.; Benabbas, R.; deSouza, I.S.; Conigliaro, A.; Paladino, L.;Warman, E., et al(2018): Utility of 2-Pyridine Aldoxime Methyl Chloride (2-PAM) for Acute Organophosphate Poisoning: A Systematic Review and Meta-Analysis. J. Med. Toxicol, 14:91-98.

Chataut, J.; Adhikari, R.K.; Sinha, N.P. and Marahata, S.B. (2011): Pattern of Organophosphorus Poisoning: A Retrospective Community Based Study. Kathmandu Univ Med J, 34(2):31-34.

Chaudhary, S.C.; Singh, K.; Sawlani, K.K.; Jain, N.; Vaish, A.K.; Atam, V., et al(2013): Prognostic Significance of Estimation of Pseudo cholinesterase Activity and Role of Pralidoxime Therapy in Organophosphorus Poisoning. Toxicol Int. , 20(3): 214-217.

Dewan, G. (2014): Analysis of recent situation of pesticide poisoning in Bangladesh: is there a proper estimate. Asia Pac J Med Toxicol, 3:76-83.

Eddleston, M. and Phillips, M.R. (2004): Self poisoning with pesticides. BMJ. , 328:42-44.

Eddleston, M.; Buckley, N.A.; Eyer, P. and Dawson, A.H. (2008): Medical management of acute organophosphorus pesticide self-poisoning. Lancet, 371:597-607.

Eddleston, M.; Eyer, P. and Worek, F. (2005): Differences between organophosphorus insecticides in human self-poisoning: aprospective cohort study. Lancet, 366: 1452-1459.

Eddleston, M. (2002): Patterns and problems of deliberate self-poisoning in the developing world. QJ Med, 93(11):715-731.

Erdman, A R.(2004):Pesticides (Insecticides). In: Dart R C (ed.), Medical Toxicology, $3^{\text {rd }}$ Edn, Lippincott Williams \& Wilkins,Philadelphia, Baltimore, New York, London, 236: 1475- 1496.

Eyer, F.; Meischner, V. and Kiderlen, D. (2003): Human parathion poisoning.A toxicokinetic analysis.Toxicol Rev, 22: 143-163.

Guven, M.; Sungur, M., Tanriverdi, M.; Eser, B. and Kekec, Z. (2002): Evaluation of the patients with acute intoxication. Turk J Med Sci , 32:169-72.
Hassan, N.A.M. and Madboly, A.G. (2013): Correlation between Serum Creatine Phosphokinase and Severity of Acute Organophosphorus Poisoning: A Prospective ClinicalStudy (2012-2013). IOSR Journal Of Environmental Science, Toxicology And Food Technology, 4(5): 18-29.

Honnakatti, V.; Nimbal, N. and Doddapattar. P. (2018): A study on serum cholinesterase level in organophosphorus poisoning and its correlation with severity of organophosphorus poisoning Vilas. International Journal of Advances in Medicine. Int $\mathbf{J}$ Adv Med, 5(4):1021-1025.

Ibrahim, M.A.; El- Masry, M.K.; Moustafa, A.A.; Abeer, M.; Hagras, A.M. and Ali, N.M.(2011): Comparison of the accuracy of two scoring systems in predicting the outcome of organophosphate intoxicated patients admitted to intensive care unit (ICU).Egyptian Journal of Forensic Sciences , 1: 41-47.

Jasem, D.Z.; Nikitha; Ramaswamy, R.; Roy, A.D. and Reddy, A M. (2014): Incidence and assessment of antidotes in organophosphate poisoning at a tertiary carehospital, south India. World J Pharm Res, 3(10):1652-1659.

Jeffery, W. and Poole, C.F. (2008): Colour tests and Thin Layer Chromatography in Clarke's Analytical Forensic Toxicology, $3^{\text {rd }}$ edition. Pharmaceutical Press,( 13): 343-372.

Jokanović, M. and Kosanović, M. (2010): "Neurotoxic effects in patients poisoned with organophosphorus pesticides." Environ Toxicol Pharmacol, 1; 29(3):195201

Kaplan, L. A.; Tobor, M. W. and Pesce, A.J. (1989): chromatography (Theory, analysis and correlation). $1^{\text {st }}$ ed. Mosby.CO. USA.73-93.

Karki, P.; Ansari, J.A.; Bhandary, S. and Koirala, S. (2004): Cardiac and electrocardiographical manifestations of acute organophosphate poisoning. Singap Med J, 45(8):385-389.

Khan, S.; Kumar, S.; Agrawal, S. and Bawankule, S. (2016): Correlation of serum cholinesterase and serum creatine phosphokinase enzymes with the severity and outcome of acute organophosphorus poisoning: study in central rural India, World Journal of Pharmacy and pharmaceutical sciences, 5(4):1365-1373.

Liu, J.: Chou, C. and Liu, Y. (2008): Acid-base interpretation can be the predictor of outcome among patients with acute organophosphatepoisoning before hospitalization. Am. J. Emerg. Med., 26: 24-30.

Mackness, M. and Mackness, B.(2014): Current aspects of paraoxonase-1 research. In Komoda T, ed. The HDL handbook: biological functions and clinical implications .2nd ed. Amsterdam: Academic Press.

Madala, P.; Aravind and Singh, M. (2017): Outcome of patients with OPC poisoning who require mechanical ventilation: a statistical analysis. Int $\mathrm{J} \mathrm{Adv}$ Med., 4(2):357-361.

Mumford, H. and Troyer, J.K. (2011):Post-exposure therapy with recombinant human BuChE following percutaneous VX challenge in guinea-pigs. Toxicol Lett. , 206:29-34. 
Patil, S.L. and Vasepalli, P. (2014): Prognostic value of clinical and lab parameters in assessing the severity of organophosphorus compound poisoning. Indian Journal of Basic and Applied Medical Research. December, 4(1): 77- 91.

Pokhrel, D.; Pant, S.; Pradhan, A. and Mansoor, S.A. (2008): comparative retrospective study of poisoning cases in central, zonal and district hospitals. Kathmandu Univ J SciEng Technol., 1(5):40-8.

Prasad, D.R.M.M.; Jirli, P.S.; Mahesh, M. and Mamatha, S. (2013): Relevance of Plasma Cholinesterase to Clinical Findings in Acute Organophosphorous Poisoning. Asia Pacific Journal of Medical Toxicology, 2(1): 23-27.

Raddi, D. and Anikethana, G .V. (2014): Clinical profile of organophosphorus poisoning in a tertiary carehospital. Indian Journal of Basic and Applied Medical Research, 4(1): 14-22.

Raghavan, P.;Amar, R.; Nayak, V.C.; Bakkannavar, S.M.; Nayak, S. and Ramachandran, A.(2014): Profile of organophosphorus insecticides poisoning in Kasturba Hospital, Manipal, South India. J Pharm Sci Innov. ,3(1):73-77.

Rajeev, H. and Arvind, M.N. (2013): Study of clinical and biochemical parameters in predicting the need for ventilator support in organophosphorus compound poisoning. J Evolution Med Dental Sci., 2(49):95559570.

Rao, C. and Kumar, L .A. (2012): Qualitative and Quantitative Analysis of Fenvalerate, And Methyl Parathion Pesticides in Mango and Grapes Collected By Hplc Method. IJSIT., 1(1): 56-68.

Ravikumar, P. and Piyush, A. (2016): Electrocardiographic Changes in Acute Organophosporus Poisoning. International Journal of Science and Research (IJSR), 5 (12):147-150.
Senanayake, N.; de Silva, H.J. and Karalliedde, L. A. (1993): scale to assess severity in organophosphorus intoxication: POP scale. Hum Exp Toxicol, 12:297299.

Shah, U.K.; Jain, H.K.;Singh, A. and Jatav, O.(2015): Clinical profile of organophosphate compoundpoisoning in a tertiary care center. International Journal of Multidisciplinary Research and Development, 2(3): 40-43.

Singh, G.and Khurana, D. (2009): Neurology of acute organophosphate poisoning. Neurol India, 57:119-125.

Singh, J.; Kapoor, D.; Singh, M. and Anand, L.K. (2016): Plasma cholinesterase levels in acute organophosphorus poisoning: a plausible marker for weaning? Anaesth Pain \& Intensive Care, 20(4):477479 .

Taromsari, M.R.; Badsar, A.; Aghajankhah, M.; Poor, M.A.; Porkar, N.F. and Karkan, M.F.(2013): The Study of Electrocardiographic Findings in Patients with Organophosphate Poisoning. Iranian Journal of Toxicology, 6 (19): 751 - 756.

Tripathi, S. (2014): Prognostic value of Glasgow coma scale, poisoning severity score and serum acetyl cholinesterase levels in organophosphorus poisoning. Journal of Evolution and Medical Dental Science, 3(13):3415-3422.

Waber, H. (1966): Kinetic colorimetric method for detection of cholinesterase. Dtsch Med Wschr, 91: 127129.

Zilker, T. and Hibler, A. (1996): Treatment of severe parathion poisoning. In :Szinicz L, Eyer P, Klimmek R, eds. Role of oximes in the treatment of anticholinesterase agent poisoning. Heidelberg: Spektrum ‘Akademischer Verlag, 9-17 . 
متنبئات الحاجة لاخول العناية الفائقة في حالات التسمم الحاد بمركبات الفسفور العضوية:دراسة مستقبلية لمدة عام

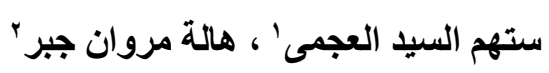

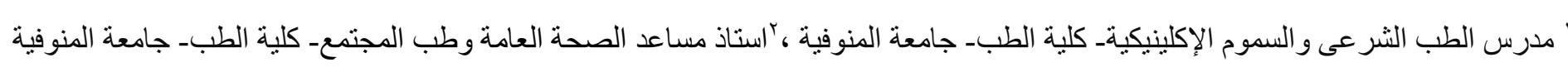

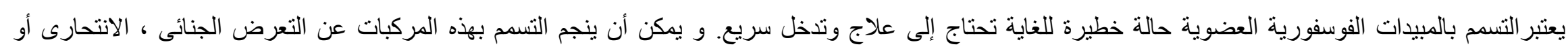

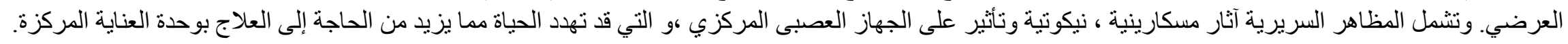
و تهدف هذه الدر اسة إلى تحديد المتنبئيات التى تساعد في اتخاذ القرار لنقل المرضى للعناية الفائقة في الوقت المناسب في حالات التسمم الفوسفوري العضوي الحاد.

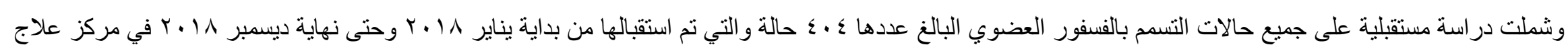

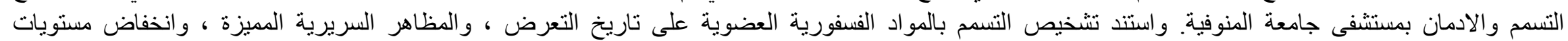
الكولينستر از في الدم و الكثف عن هذه المركبات في السوائل البيولوجية بولئ باسطة كروماتو غر افيا الطبقة الرقيقة.

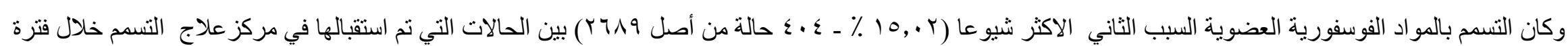

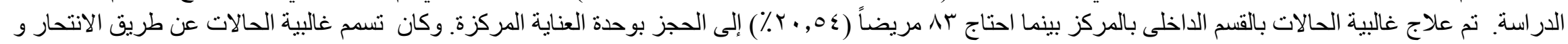

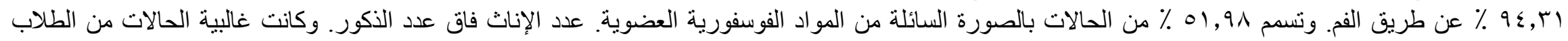

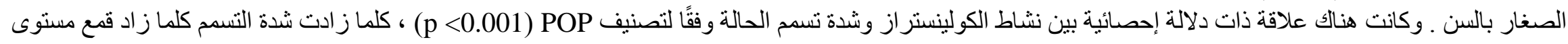

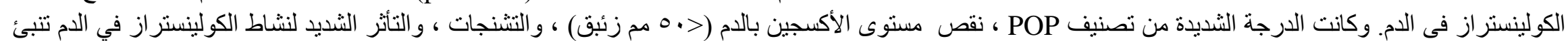
بشكل كبيرلحاجة المرضى اللعلاج بوحدة العناية المركزة.

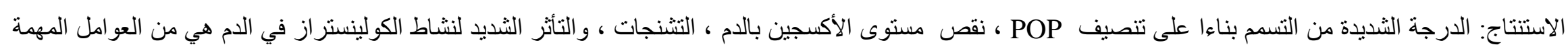

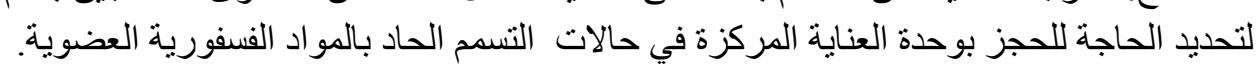

